\title{
TINGKAT PEMAHAMAN MAHASISWA AKUNTANSI TERHADAP KONSEP DASAR AKUNTANSI DI PERGURUAN TINGGI NEGERI DI KOTA MALANG
}

\author{
M. Cholid Mawardi \\ Prodi Akuntansi Fakultas Ekonomi Universitas Islam (UNISMA) Malang \\ Jl. MT. Haryono 193 Malang
}

\begin{abstract}
The purpose of this study was to measure the gap of understanding that comes from the vocational school students majoring in accounting, high school social studies and Madrasah Aliyah Department of General of the basic concepts of accounting. The basic concept of accounting is used as a variable in this research that the assets, liabilities and capital. Techniques of data collection in this research using questionnaires. Population and sample in this study were 100 students majoring in accounting at the State Universities in Malang City listed as an active student for the academic year 2010/2011 and has completed introductory accounting courses I and II. This study uses a different test Kruskal Wallis to measure the gap of understanding that comes from the vocational school students majoring in accounting, high school social studies majors and Madrasah Aliyah General of the basic concepts of accounting. The results show that, of the three variables are used as the measurement of differences in levels of student understanding of basic concepts of accounting are assets, liabilities, capital and otherwise there is no students' understanding of basic concepts of accounting. From the mean rank of three variables it is seen that students from Madrasah Aliyah better understand the basic concepts of accounting compared to students from SMK Accounting Department and high school social studies majors.
\end{abstract}

Key words: Assets, liabilities, capital and accounting students.

Akuntansi dapat dipandang sebagai bidang pengetahuan teknologi yang menyusut pada berbagai ilmu pengetahuan dan membentuk seperangkat pengetahuan akuntansi. Akibat perkembangan ekonomi, perdagangan luar negeri, komunikasi, dan teknologi maka pemanfaatan teknologi informasi akuntansi menjadi semakin luas dan canggih dalam berbagai bidang dan organisasi. Kemudian berkembanglah pengetahuan-pengetahuan khusus di dalam seperangkat pengetahuan akuntansi, terlepas dari sudut pandang siapa pemakai laporan keuangan tersebut. Didalam praktik, keahlian dalam pengetahuan khusus ini menjadi spesialisasi pekerjaan di bidang akuntansi. Perkembangan ini 
kemudian menjadi dasar pemikiran dalam pengembangan kurikulum pendidikan akuntansi.

Pengetahuan yang dibutuhkan untuk akuntan menurut hasil evolusi pendidikan terdiri dari pengetahuan umum, organisasi, bisnis, dan akuntansi. Untuk memperoleh pengetahuan tersebut maka pengetahuan tentang dasar-dasar akuntansi merupakan suatu kunci utama, diharapkan dengan adanya dasar-dasar akuntansi sebagai pegangan, maka semua praktik dan teori akuntansi akan dengan mudah dilaksanakan. Namun, kenyataannya pendidikan akuntansi yang selama ini diajarkan di perguruan tinggi hanya terkesan sebagai pengetahuan yang berorientasi pada mekanisme secara umum saja, sangat berbeda apabila dibandingkan dengan praktik yang sesungguhnya yang dihadapi di dunia kerja nantinya. Masalah tersebut tentu saja akan mempersulit bahkan membingungkan mahasiswa untuk mendapatkan pemahaman tentang konsep dasar akuntansi. Dengan demikian tingkat pendidikan di perguruan tinggi masih menunjukkan hasil yang tidak sesuai dengan yang diharapkan, padahal proses belajar mengajar pada pendidikan tinggi akuntansi hendaknya dapat mentranformasikan peserta didik menjadi lulusan yang lebih utuh sebagai manusia.

Menurut Budhiyanto dan Ika paskah (2004), Tingkat pemahaman akuntansi mahasiswa dinyatakan dengan seberapa mengerti seorang mahasiswa terhadap apa yang sudah dipelajari yang dalam konteks ini mengacu pada mata kuliah akuntansi dan Indeks Prestasi Kumulatif (IPK). Tanda seorang mahasiswa memahami akuntansi tidak hanya ditujukan dari nilai-nilai yang didapatkannya dalam mata kuliah tetapi juga apabila mahasiswa tersebut mengerti dan dapat menguasai konsep-konsep yang terkait.

Pada semester awal, setiap perguruan tinggi mewajibkan mahasiswa jurusan akuntansi untuk mengikuti perkuliahan Akuntansi Pengantar. Sebagai mata kuliah yang diajarkan pada semester pertama di tahun pertama, tidak disangsikan lagi mata kuliah ini memegang peranan penting dan menentukan dalam mengantarkan para mahasiswa yang akan mempelajari akuntansi dan mata kuliah lain yang berkaitan pada tahapan berikutnya. Sebagai mata kuliah pengantar, mata kuliah ini dimaksudkan untuk memberikan pengetahuan dasar atau fundamen kepada para mahasiswa. Oleh karena itu bangunan pengetahuan 
akuntansi yang dimiliki mahasiswa kelak, akan banyak dipengaruhi oleh keberhasilan pembelajaran mata kuliah ini sebagai fundamennya.

Pada mata kuliah akuntansi pengantar diharapkan agar mahasiswa dapat memahami konsep dasar akuntansi secara baik. Menurut Munawir (2004) ada tiga materi pokok tentang konsep dasar akuntansi yang harus dikuasai oleh mahasiswa akuntansi dalam kuliah Akuntansi Pengantar, yaitu pemahaman tentang aktiva, Kewajiban, dan modal. Dari ketiga materi tersebut mahasiswa diharapkan dapat mengikuti perkuliahan dengan baik dan benar karena dengan penguasaan yang baik terhadap aktiva, kewajiban, dan modal akan mempermudah mahasiswa untuk memahami semua masalah-masalah yang akan ditemui dalam akuntansi. Mahasiswa akuntansi memandang mata kuliah Akuntansi Pengantar sebagai mata kuliah pokok yang akan memberi landasan penting dan memberi pengaruh yang besar pada keberhasilan mereka dalam menempuh mata kuliah akuntansi lain yang akan ditempuh pada tahun-tahun berikutnya. Penelitian ini bertujuan untuk menganalisis apakah terdapat perbedaan secara signifikan terhadap pemahaman tentang aktiva, kewajiban dan modal serta seberapa besar pemahaman aktiva, kewajiban dan modal antara mahasiswa yang berasal dari SMK Jurusan Akuntansi, SMA Jurusan IPS, dan Madrasah Aliyah Umum.

Penelitian yang dilakukan oleh Sar'i, Irsadsyah, dan Djamil (2010) bertujuan untuk mengukur perbedaan pemahaman dan seberapa besar pemahaman mahasiswa yang berasal dari SMK Jurusan Akuntansi, SMA Jurusan IPS, dan Madrasah Aliyah Umum terhadap konsep dasar akuntansi. Untuk sampel yang digunakan adalah mahasiswa semester 3 jurusan akuntansi S1 UIN Suska Riau yang aktif untuk tahun ajaran 2009/2010 yang berasal dari SMK Jurusan Akuntansi, SMA Jurusan IPS, dan Madrasah Aliyah Umum dan alat analisis yang digunakan adalah uji Kruskal Wallis.

Hasil penelitian menyatakan dari tiga variabel yang dijadikan pengukuran perbedaan tingkat pemahaman mahasiswa terhadap konsep dasar akuntansi yaitu aktiva, kewajiban, dan modal hanya satu variabel yang dinyatakan terdapat perbedaan pemahaman mahasiswa terhadap konsep dasar akuntansi tentang modal. Disamping itu tidak terdapat perbedaan pemahaman mahasiswa terhadap konsep dasar akuntansi tentang aktiva dan kewajiban. Dari nilai mean rank ketiga 
variabel maka terlihat bahwa mahasiswa yang berasal dari Madrasah Aliyah lebih memahami konsep dasar akuntansi dibandingkan mahasiswa yang berasal dari SMK dan mahasiswa yang berasal dari SMA.

Penelitian yang dilakukan oleh Novius (2010) yang bertujuan untuk membuktikan secara empiris tentang kemampuan mahasiswa yang berasal dari SMK Jurusan Akuntansi, SMA Jurusan IPS dan Madrasah Aliyah Umum dalam memahami mata kuliah pengantar akuntansi. Dasar-dasar akuntansi yang dijadikan sebagai variabel dalam penelitian ini yaitu aktiva, kewajiban dan modal. Teknik pengumpulan data dalam penelitian ini adalah dengan menggunakan kuesioner. Yang menjadi populasi dan sampel dalam penelitian ini adalah 60 orang mahasiswa Jurusan Akuntansi S1 UIN Suska Riau yang terdaftar sebagai mahasiswa semester 3, 5, dan 7 yang aktif untuk tahun ajaran 2009/2010 dan telah menyelesaikan mata kuliah pengantar akuntansi 1 dan 2.

Penelitian ini menggunakan uji beda yaitu uji Kruskal Wallis yaitu untuk mengetahui perbedaan pemahaman tentang aktiva, kewajiban dan modal antara mahasiswa berasal dari SMK Jurusan Akuntansi, SMA Jurusan IPS dan Madrasah Aliyah Umum. Hasil penelitian menunjukkan pada semua variabel yaitu aktiva, kewajiban dan modal didapatkan hasil bahwa semua hipotesis ditolak karena chisquare tabel 75,624 > chi-square hitung pada semua variabel, sedangkan berdasarkan nilai probabilitas signifikasi semua variabel juga menunjukkan bahwa a $>0,0$ atau 5\%5. Dari hasil tersebut diperoleh hasil dari penelitian ini bahwa tidak terdapat perbedaan secara signifikan terhadap pemahaman tentang aktiva, kewajiban dan modal antara mahasiswa yang berasal dari SMK Jurusan Akuntansi, SMA Jurusan IPS dan Madrasah Aliyah Umum. Dengan demikian diputuskan bahwa pemahaman mahasiswa terhadap dasar-dasar akuntansi tidaklah berbeda ataupun identik antara satu sama lainnya. Sekolah asal yang berbeda ternyata tidak menjadi faktor perbedaan bagi mahasiswa untuk memahami dasardasar akuntansi.

Pendidikan merupakan pengaruh lingkungan terhadap individu untuk menghasilkan perubahan-perubahan yang tetap dalam kebiasaan perilaku, pikiran dan sikapnya. Pendidikan formal adalah pendidikan di sekolah/perguruan tinggi yang berlangsung secara teratur dan bertingkat mengikuti syarat-syarat yang jelas 
dan ketat. Tujuan pendidik adalah untuk memperkaya budi pekerti, pengetahuan dan untuk menyiapkan seseorang agar mampu dan trampil dalam suatu bidang pekerjaan tertentu. Pendidikan di perguruan tinggi, metode konvensional merupakan motode pembelajaran yang biasa dilaksanakan dan disukai oleh dosen dalam proses pembelajaran sehari-hari, karena paling mudah cara mengatur kelas.

Pendidikan Tinggi merupakan kelanjutan pendidikan menengah yang diselenggarakan untuk menyiapkan peserta didik menjadi anggota masyarakat yang memiliki kemampuan akademik dan/atau profesional yang dapat menerapkan, mengembangkan dan/atau menciptakan ilmu pengetahuan, teknologi dan/atau kesenian (Mudyahardjo, 2008).

Dalam Peraturan Pemerintah Nomor 60 Tahun 1999 yang dimaksud dengan pendidikan tinggi adalah pendidikan pada jalur pendidikan sekolah pada jenjang yang lebih tinggi daripada pendidikan menengah di jalur pendidikan sekolah. Tujuan pendidikan tinggi adalah (1) menyiapkan peserta didik menjadi anggota masyarakat yang memiliki kemampuan akademik dan/atau profesional yang dapat menerapkan, mengembangkan dan/atau memperkaya khasanah ilmu pengetahuan, teknologi dan/atau kesenian, (2) mengembangkan dan menyebarluaskan ilmu pengetahuan, teknologi dan/atau kesenian serta mengupayakan penggunaannya untuk meningkatkan taraf kehidupan masyarakat dan memperkaya kebudayaan nasional

Pendidikan di perguruan tinggi, metode konvensional merupakan metode pembelajaran yang biasa dilaksanakan dan disukai oleh dosen dalam proses pembelajaran sehari-hari, karena paling mudah cara mengatuir kelas. Menurut Wina (2005) dalam model pembelajaran konvensional mahasiswa ditempatkan sebagai objek belajar yang berperan sebagai penerima informasi secara pasif dan mahasiswa lebih banyak belajar secara individual dengan menerima, mencatatdan menghafal materi. Metode konvensional lebih menenkankan pada metode ceramah, metode ceramah adalah penuturan bahan perkuliahan secara lisan (Nana, 2005).

Konsep dasar pemahaman akuntansi menurut (Munawir, 2004) terdiri dari tiga bagian utama yaitu aktiva, hutang dan modal. Dalam pengertian aktiva tidak terbatas pada kekayaan perusahaan yang berwujud saja, tetapi juga termasuk 
pengeluaran-pengeluaran yang belum dialokasikan (deffered changes) atau biaya yang masih harus dialokasikan pada penghasilan yang akan datang, serta aktiva yang tidak berwujud lainnya (intangible asset) misalnya goodwill, hak paten, hak menerbitkan dan sebagainya.

Tingkat pemahaman akuntansi merupakan sejauh mana kemampuan untuk memahami akuntansi baik sebagai seperangkat pengetahuan (body of knowledge) maupun sebagai proses atau praktik. Penguasaan pengetahuan atau keterampilan yang dikembangkan oleh mata pelajaran, lazimnya ditunjukkan dengan nilai tes atau angka yang diberikan oleh guru/dosen (Muliono dalam Hanifah \& Abdullah, 2001). Nilai yang diperoleh peserta didik mempunyai fungsi ganda, sebagai ukuran keberhasilan peserta didik dalam mempelajari mata kuliah dan sekaligus sebagai alat evaluasi keberhasilan mata kuliah itu sendiri (Suwardjono, 1992:157 dalam hanifah \& Abdullah, 2003).

Dalam hal tertentu, nilai yang diperoleh mahasiswa merupakan indikator kesuksesan mahasiswa dalam menempuh kuliah, tetapi mungkin bukan merupakan ukuran keberhasilan pencapaian tujuan atau sasaran pengajaran mata kuliah dalam mengubah pengetahuan, perilaku atau kepribadian mahasiswa termasuk penalarannya.

Hutang adalah semua kewajiban keuangan perusahaan kepada pihak lain yang belum terpenuhi, dimana hutang ini merupakan sumber dana atau modal perusahaan yang berasal dari kreditur. Hutang atau kewajiban perusahaan dapat dibedakan ke dalam hutang lancar (hutang jangka pendek) dan hutang jangka panjang (Munawir, 2004). Menurut Kieso \& Weygant (1998) adalah pengorbanan manfaat ekonomi di masa yang akan datang sebagai akibat dari kewajiban yang ditimbulkan sekarnag ini, sedangkan menurut Baridwan (1999), hutang adalah kewajiban yang ditimbulkan dari transaksi-transaksi di masa lalu yang digunakan untuk mendapatkan aktiva atau jasa yang pembayarannya dilakukan di masa yang akan datang.

Berdasarkan pendapat di atas dapat disimpulkan bawa utang adalah semua kewajiban keuangan perusahaan kepada pihak lain yang belum dipenuhi, di mana hutang ini merupakan sumber modal perusahaan yang berasal dari kreditur dan harus dibayar dengan uang, barang, atau jasa pada saat jatuh tempo. Hutang 
merupakan sumber pendapatan yang dapat membantu jalannya usaha, hutang ini juga digunakan untuk membantu perusahaan di bidang opersional, keuanagan, dan investasi. Perjanjian hutang dapat dikelompokkan ke dalam dua bentuk, kadang mengacu sebagai perjanjian negatif dan positif (Janes, 2003). Perjanjian negatif umumnya menunjukkan aktivitas tertentu yang mengakibatkan substitusi aset atau masalah pembayaran kembali. Contoh perjanjian hutang negatif mencakup larangan terhadap merger, batasan peminjaman tambahan, batasan pembayaran dividen dan excess cash sweeps.

Perjanjian positif mensyaratkan peminjam melakukan tindakan tertentu, seperti menjaminkan aset atau memenuhi benchmark tertentu (biasanya rasiorasio keuangan) yang mengindikasikan kesehatan keuangan. Contoh umum perjanjian hutang positif mencakup tingkat rasio current, leverage, probabilitas dan net worth minimal atau maksimum.

Jadi perjanjian hutang baik bentuk negatif maupun positif dapat digunakan untuk membatasi konflik kepentingan yang potensial terjadi antara kreditur dan stakeholders perusahaan. Hutang yang dipergunakan secara efektif dan efisien akan meningkatkan nilai perusahaan (Herry dan Hamin, 2005) menunjukkan bahwa leverage menyebabkan peningkatan nilai perusahaan (value enchancing).

Berdasarkan jangka waktunya hutang dibagi atas dua jenis yaitu hutang jangka pendek dan hutang jangka panjang.

1. Hutang Lancar (Hutang Jangka Pendek)

Kadang kala perusahaan meminjam uang dalam jangka pendek untuk kegiatan operasi perusahaan yang biasa disebut dengan hutang hutang (kewajiban) jangka pendek atau lancar. Yusuf (2005) mendefinisikannya sebagai berikut: "Kewajiban lancar adalah hutang yang diharapkan akan dibayar (1) dalam jangka waktu satu tahun atau siklus akuntansi operasi normal perusahaan, (2) dengan menggunakan aktiva lancar atau hasil pembentukan kewajiban lancar yang lain".

Sedangkan menurut FASB, Concepts No. 3 adalah:

"Pengorbanan manfaat ekonomi di masa yang akan datang yang mungkin terjadi akibat kewajiban suatu badan usaha pada masa kini untuk mentransfer aktiva atau menyediakan jasa pada badan usaha lain di masa yang akan datang sebagai akibat transaksi atau kejadian di masa lalu" 
Berdasarkan pengertian-pengertian diatas dapat disimpulkan bahwa utang jangka pendek adalah kewajiban yang akan jatuh tempo dalam waktu satu tahun atau siklus operasi normal perrusahaan dan harus dilunasi dengan menggunakan aktiva lancar, serta kewajiban tersebut berdasarkan transaksi yang telah terjadi. Hutang jangka pendek atau yang disebut juga dengan hutang lancar adalah kewajiban yang harus dilunasi dalam jangka waktu kurang dari satu tahun. Elemen-elemen hutang jangka pendek atau hutang lancar antara lain: (1) Hutang Dagang (Account Payable) (2) Wesel Bayar (Note Payable), (3) Beban yang Masih Harus Dibayar (Accrued Expenses), (4) Hutang atau Kewajiban Bersyarat (Contingent Liabilities) (5) Pendapatan yang Diterima Dimuka

\section{Hutang Jangka Panjang}

Hutang jangka panjang menurut Kieso (2002) : “Terdiri dari pengorbanan manfaat ekonomi yang sangat mungkin di masa depan akibat kewajiban sekarang yang tidak dibayarkan dalam satu tahun atau siklus operasi perusahaan, mana yang lebih lama". Sedangkan Baridwan (2000) mengatakan bahwa: "Hutang jangka panjang digunakan untuk menunjukkan hutanghutang yang pelunasannya akan dilakukan dalam waktu lebih dari satu tahun atau akan dilunasi dari sumber-sumber yang bukan dari kelompok aktiva lancar". Pendapat senada dengan pendapat yang dikemukakan oleh Gunadi (2005) bahwa : "Kewajiban jangka panjang merupakan hutang yang tidak akan jatuh tempo dalam waktu satu tahun atau yang pengeluarannya tidak menggunakan sumber aktiva lancar".

Berdasarkan definisi dan penjelasan para ahli di atas, maka dapat disimpulkan bahwa hutang jangka panjang merupakan pinjaman yang diperoleh perusahaan dari pihak ketiga atau kreditor, yang jatuh temponya lebih dari satu tahun, dan dilunasi dengan sumber-sumber yang bukan dari aktiva lancar, serta jumlah hutang jangka panjang tersebut tidak boleh melebihi jumlah modal sendiri. Elemen-elemen hutang jangka panjang antara lain: (1) Kredit Investasi (Long Term Loan), (2) Hutang hipotik (Mortgage Payable), (3) Hutang Obligasi (Bond Payable), (4) Hutang Kepada Pemegang Saham atau Kepada Perusahaan Induk (Holding Company) atau Kepada 
Perusahaan Afiliasi (Afiliated Company), (5) Hutang Subordinasi

(Subordinated Loan), (6) Ridging Loan, (7) Hutang Leasing (Hutang dalam Rangka Sewa Guna)

Modal adalah merupakan hak atau bagian yang dimiliki oleh pemilik Perusahaan yang ditunjukkan dalam pos modal (modal saham), surplus dan laba yang ditahan. Atau kelebihan nilai aktiva yang dimiliki oleh perusahaan terhadap seluruh hutang-hutangnya (Munawir, 2004). Adapun jenis modal antara lain: (a) Modal Sendiri, yang terdiri modal saham, tambahan modal disetor / agio saham, hadiah / donasi. (b) Laba yang ditahan (Retained Earning). (c) Modal Penilaian (Appraisal Capital).

\section{HIPOTESIS}

Dari penjelasan diatas dapat dirumuskan hipotesis penelitian sebagai berikut : (a) Terdapat perbedaan secara signifikan terhadap tingkat pemahaman aktiva antara mahasiswa berasal dari SMK Jurusan Akuntansi, SMA Jurusan IPS dan Madrasah Aliyah Umum. (b) Terdapat perbedaan secara signifikan terhadap tingkat pemahaman kewajiban antara mahasiswa berasal dari SMK Jurusan Akuntansi, SMA Jurusan IPS dan Madrasah Aliyah Umum. (c) Terdapat perbedaan secara signifikan terhadap tingkat pemahaman modal antara mahasiswa berasal dari SMK Jurusan Akuntansi, SMA Jurusan IPS dan Madrasah Aliyah Umum.

\section{METODE}

Penelitian ini termasuk penelitian empiris (empirical research) atau kuantitatif yaitu penelitian terhadap fakta empiris yang diperoleh berdasarkan observasi atau pengamatan. Penelitian ini memerlukan kehadiran peneliti untuk melakukan observasi terhadap fakta atau segala sesuatu yang dialaminya tanpa perantara orang lain. Menurut tujuan studi, penelitian ini merupakan penelitian untuk menguji hipotesis (Indiantoro dan Supomo, 1999:29).

Dalam penelitian ini metode pengambilan sampel yang dilakukan adalah metode stratified random sampling yaitu pengambilan sampel berdasarkan bagiannya yaitu sekolah asal mahasiswa tersebut. Kriteria Sampel dalam penelitian ini adalah mahasiswa jurusan akuntansi di Perguruan Tinggi Negeri di 
Kota Malang yang terdaftar sebagai mahasiswa aktif untuk ajaran 2010/2011 dan telah menyelesaikan mata kuliah pengantar akuntansi I, pengantar akuntansi II. Populasi dalam penelitian ini berjumlah 513 mahasiswa jurusan akuntansi yang terdiri dari : mahasiswa Universitas Brawijaya berjumlah 280 mahasiswa, dan Universitas Islam Negeri Maulana Malik Ibrahim Malang berjumlah 233 mahasiswa.

Penentuan jumlah sampel ditentukan dengan menggunakan rumus Slovin dalam Umar (2002:146) sebagai berikut:

$$
n=\frac{N}{1+N(e)^{2}}
$$

Keterangan :

n : Jumlah sampel

$\mathrm{N} \quad$ : jumlah populasi

e : Nilai kritis (batasan ketelitian) yang diinginkan (persen kelonggaran ketidaktelitian karena pengambilan sampel populasi) sebesar $10 \%$.

Jadi jumlah sampel dalam penelitian ini adalah:

$$
\begin{aligned}
& n=\frac{513}{1+513(10 \%)^{2}} \\
& n=\frac{513}{5,14} \\
& n=99,805=100
\end{aligned}
$$

Setelah melakukan perhitungan dengan menggunakan rumus Slovin, maka diketahui sampel sebanyak 100 sampel (mahasiswa).

Penelitian ini menggunakan sumber data primer (primary data) merupakan sumber data penelitian yang diperoleh secara langsung dari sumber asli (tidak melalui perantara) dan secara khusus dikumpulkan oleh peneliti untuk menjawab pertanyaan penelitian (Indriantoro dan Supomo, 1999:143). Sumber data primer yang digunakan dalam penelitian ini adalah hasil penyebaran kuisioner atau angket yang diberikan secara langsung. Sedangkan Metode pengumpulan data dalam penelitian ini adalah dengan menggunakan metode kuisioner. 
Metode analisis data yang digunakan untuk menguji hipotesis dalam penelitian ini yaitu menggunakan uji data tiga sampel (independen) yang tidak berhubungan yaitu uji Kruskall Wallis. Sebelum dilakukan uji kruskall wallis, terlebih dahulu dilakukan uji kualitas dan normalitas data. Pengujian kualitas data dilakukan dengan dua cara, yaitu validitas dan realibilitas. Untuk memilih data yang instrumen penelitian yang dapat diandalkan kemampuannya, maka harus dilakukan uji validitas dan uji realibilitas terhadap alat ukur tersebut supaya diperoleh representatif dalam penelitian.

\section{Uji Validitas}

Indriantoro \& Supomo $(2002 ; 181)$ mengemukakan bahwa validitas data penelitian ditentukan oleh proses pengukuran data yang akurat. Oleh karena itu, jika ada sinonim dari realibilitas yang paling tepat adalah akurasi. Suatu instrumen pengukuran dikatakan valid jika instrumen tersebut mengukur apa yang seharusnya diukur. Dengan perkataan lain instrumen tersebut dapat mengukur construct sesuai dengan yang diharapkan oleh peneliti. Menurut Kaiser dan Rice (1974), untuk menunjukkan Construct Validity dari masing-masing variabel, maka nilai Kaiser Meyer Olkin Measure Of Sampling Adequacy (Kaiser MSA) mengisyaratkan agar data yang terkumpul dapat tepat dilakukan analisis faktor nilainya minimal 0,50. Adapun teknik validitas yang dilakukan melalui analisis butir soal dengan bantuan program komputer SPSS 11.01 For Windows.

\section{Uji Realibilitas}

Realibilitas mengarah pada suatu pengertian bahwa suatu instrumen cukup dapat digunakan sebagai alat pengumpul data, karena instrumen tersebut sudah baik (Arikunto, 1998:170). Uji realibilitas menunjukkan sejauh mana suatu hasil pengukuran relatif konsisten apabila pengukuran dilakukan beberapa kali. Teknik yang digunakan untuk mengukur realibilits (keandalan) dalam penelitian ini adalah teknik Cronbach Alpha. Instrumen yang dipakai dalam variabel tersebut dikatakan andal (realible), apabila memiliki nilai Cronbach Alpha lebih dari 0,6 (Nunnaly, 1978) dalam Wahyuni (2006).

Sedangkan uji normalitas menggunakan uji-Kormogorov Smirnov (One-Sample Kolmogorov-Smirnov Test). 


\section{Uji Kruskal Wallis}

Uji Kruskal wallis adalah uji nonparametrik yang digunakan untuk membandingkan tiga atau lebih kelompok data sampel. Penyusunan hipotesis dalam uji Kruskal Wallis adalah sebagai berikut:

$\mathrm{H}_{0}$ : sampel berasal dari populasi yang sama $(\mu 1=\mu 2=\ldots=\mu \mathrm{k})$

$\mathrm{H}_{\mathrm{a}}$ : sampel berasal dari populasi yang berbeda $(\mu \mathrm{i}=\mu \mathrm{j})$

Rumus umum yang digunakan pada uji kruskal wallis adalah :

$$
K=\frac{12}{N(N+1)} \sum_{i=1}^{k} \frac{R i^{2}}{n i}-3(N+1)
$$

Dimana :

$\mathrm{K}=$ nilai Kruskal-Wallis dari hasilperhitungan

$\mathrm{Ri}=$ jumlah rank dari kategori/perlakuan ke $\mathrm{i}$

$\mathrm{Ni}=$ Banyaknya ulanganpada kategori/perlakuan ke-i

$\mathrm{K} \quad$ = banyaknya kategori/perlakuan $(\mathrm{i}=1,2,3, \ldots \ldots, \mathrm{k})$

$\mathrm{N}=$ Jumlah seluruh data $(\mathrm{N}=\mathrm{n} 1+\mathrm{n} 2+\mathrm{n} 3+\ldots \ldots \ldots+\mathrm{nk})$

Kriteria penerimaan Ho adalah sebagai berikut :

a. Jika Statistik Hitung < Statistik Tabel, maka Ho diterima.

b. Jika Statistik Hitung > Statistik Tabel, maka Ho ditolak.

\section{PEMBAHASAN}

Hasil statistik deskriptif dari skor konsep dasar akuntansi masing-masing item dapat dilihat pada tabel berikut:

\section{Tabel 1. Descriptive Statistik}

\begin{tabular}{|c|c|c|c|c|r|}
\hline & $\mathrm{N}$ & Minimum & Maximum & Mean & Std. Deviation \\
\hline Aktiva & 100 & 2.20 & 5.00 & 3.9330 & .62086 \\
Kewajiban & 100 & 2.20 & 5.00 & 4.0130 & .54414 \\
Modal & 100 & 2.10 & 4.90 & 3.7330 & .56462 \\
Valid N (listwise) & 100 & & & & \\
\hline
\end{tabular}

Statistik deskriptif untuk variabel aktiva memiliki nilai rata-rata sebesar 3,9330 dengan nilai minimum sebesar 2,20 dan nilai maksimum 5,00, sedangkan standar deviasinya sebesar 0,62086 . Variabel kewajiban memiliki nilai rata-rata 
4,0130 dengan nilai minimum 2,20 dan nilai maksimum5,00, sedangkan standar deviasinya sebesar 0,54414 . Variabel modal diperoleh nilai rata-rata 3,7330 dengan nilai minimum 2,10 dan nilai maksimum 4,90, sedangkan standar deviasinya sebesar 0,56462 .

Hasil pengujian validitas dan realibilitas yaitu sebagai berikut:

Tabel 2. Hasil Uji Validitas dan Realibilitas Data

\begin{tabular}{|c|c|c|c|r|}
\hline \multirow{2}{*}{ Variabel } & \multicolumn{2}{|c|}{ Validitas } & \multicolumn{2}{c|}{ Realibilitas } \\
\cline { 2 - 5 } & KMO & Keputusan & Cronbach'alpha & Keputusan \\
\hline AKTIVA & 0,878 & Valid & 0.872 & Reliabel \\
\hline KEWAJIBAN & 0.825 & Valid & 0.863 & Reliabel \\
\hline MODAL & 0,772 & Valid & 0.814 & Reliabel \\
\hline
\end{tabular}

Berdasarkan tabel diatas dapat dijelaskan bahwa hasil uji realibilitas dan validitas terhadap 100 sampel yang diukur dengan 30 item pertanyaan yang terdiri dari :

1. Variabel aktiva diukur dengan 10 item pertanyaan. Setelah dilakukan uji realibilitas, nilai Cronbach alpha adalah 0,872 yang berarti variabel tersebut reliabel, karena memiliki Cronbach alpha diatas 0,60. Hasil uji validitas menunjukkan bahwa instrumen penelitian variabel aktiva memiliki KMO-MSA sebesar 0,878, karena nilai KMO-MSA pada instrumen variabel aktiva > 0.05 maka instrumen penelitian variabel aktiva memenuhi syarat untuk valid.

2. Variabel kewajiban diukur dengan 10 item pertanyaan. Setelah dilakukan uji realibilitas, nilai Cronbach alpha adalah 0,863 yang berarti variabel tersebut reliabel, karena memiliki Cronbach alpha diatas 0,60. Hasil uji validitas menunjukkan bahwa instrumen penelitian variabel kewajiban memiliki KMO-MSA sebesar 0,825, karena nilai KMO-MSA pada instrumen variabel kewajiban > 0.05 maka instrumen penelitian variabel kewajiban memenuhi syarat untuk valid.

3. Variabel modal diukur dengan 10 item pertanyaan. Setelah dilakukan uji realibilitas, nilai Cronbach alpha adalah 0,814 yang berarti variabel tersebut reliabel, karena memiliki Cronbach alpha diatas 0,60. Hasil uji validitas menunjukkan bahwa instrumen penelitian variabel modal memiliki KMO-MSA sebesar 0,772, karena nilai KMO-MSA pada 
instrumen variabel modal > 0.05 maka instrumen penelitian variabel modal memenuhi syarat untuk valid.

Pengujian normalitas data tersebut menggunakan One Sample Kormogorov Smirnov test, dengan syarat jika asym sig (2-tailed) > 0,05 maka data tersebut berdistribusi normal. Sebaliknya jika asym sig (2-tailed) <0,05 maka data berdistribusi tidak normal.

Hasil Uji Normalitas Data One-Sample Kolmogorov-Smirnov Test

\begin{tabular}{|c|c|c|c|c|}
\hline & & Aktiva & Kewajiban & Modal \\
\hline \multicolumn{2}{|l|}{$\mathrm{N}$} & 100 & 100 & 100 \\
\hline \multirow{5}{*}{ Most Extreme Differences } & Mean & 3.9330 & 4.0130 & 3.7330 \\
\hline & Std. Deviation & 62086 & .54414 & .56462 \\
\hline & Absolute & .145 & .118 & .127 \\
\hline & Positive & .057 & .086 & .063 \\
\hline & Negative & -.145 & -.118 & -.127 \\
\hline \multicolumn{2}{|l|}{ Kolmogorov-Smirnov Z } & 1.452 & 1.177 & 1.267 \\
\hline \multicolumn{2}{|l|}{ Asymp. Sig. (2-tailed) } & .030 & .125 & .081 \\
\hline
\end{tabular}

Berdasarkan hasil uji normalitas data dengan metode One Sample kolmogorov Smirnov test., untuk variabel aktiva menunjukkan nilai KolmogorovSmirnovZ sebesar 1,452 dengan signifikansi sebesar 0,030. Nilai Kolmogorov SmirnovZ untuk variabel kewajiban menunjukkan nilai 1,177 dengan signifikansi sebesar 0,125. Dan nilai Kolmogorov-SmirnovZ untuk variabel modal sebesar 1,267 dengan signifikansisebesar 0,081. Dapat dketahui bahwa seluruh variabel memiliki nilai Kolmogorov-SmirnovZ diatas 0,05, maka dapat disimpulkan bahwa seluruh variabel berdistribusi normal dan layak digunakan digunakan sebagai data penelitian.

\section{Uji Kruskall Wallis}

Pengujian hipotesis menggunakan uji data tiga sampel (independen) yang tidak berhubungan yaitu uji Kruskall Wallis,untuk mengetahui perbedaan pemahaman tentang aktiva, kewajiban, dan modal antara mahasiswa yang berasal dari SMK jurusan akuntansi, SMA jurusan IPS, dan Madrasah Aliyah Umum. Hasil Uji Kruskall Wallis dapat dilihat pada tabel berikut:

\section{Hasil Uji Beda Kruskall Wallis}

\begin{tabular}{|c|c|c|c|c|c|c|c|}
\hline H & Variabel & Mahasiswa & $\mathbf{n}$ & $\begin{array}{c}\text { Mean } \\
\text { Rank }\end{array}$ & $\begin{array}{c}\text { Kruskall Wallis } \\
\text { Test }\end{array}$ & Asumsi & $\begin{array}{c}\text { Penerimaan } \\
\text { Hipotesis }\end{array}$ \\
\hline
\end{tabular}




\begin{tabular}{|c|c|c|c|c|c|c|c|}
\hline & & & & & Chi-Square & Sig (2-tailed) & \\
\hline \multirow{3}{*}{$\mathrm{H} 1$} & \multirow{3}{*}{ AKTIVA } & SMK & 32 & 46,03 & \multirow{3}{*}{2,077} & \multirow{3}{*}{0,354} & \multirow{3}{*}{ DITOLAK } \\
\hline & & SMA & 37 & 50,02 & & & \\
\hline & & Aliyah & 31 & 56,21 & & & \\
\hline \multirow{3}{*}{$\mathrm{H} 2$} & \multirow{3}{*}{ KEWAJIBAN } & SMK & 32 & 45,99 & \multirow{3}{*}{1,653} & \multirow{3}{*}{0,438} & \multirow{3}{*}{ DITOLAK } \\
\hline & & SMA & 37 & 51,18 & & & \\
\hline & & Aliyah & 31 & 55,02 & & & \\
\hline \multirow{3}{*}{$\mathrm{H} 3$} & \multirow{3}{*}{ MODAL } & SMK & 32 & 50,46 & \multirow{3}{*}{1,850} & \multirow{3}{*}{0,397} & \multirow{3}{*}{ DITOLAK } \\
\hline & & SMA & 37 & 45,76 & & & \\
\hline & & Aliyah & 31 & 55,60 & & & \\
\hline \multicolumn{8}{|c|}{ CHISQ Tabel $=124,342$} \\
\hline
\end{tabular}

Berdasarkan tabel diatas dapat dilihat pengujian hipotesis dalam penelitian ini adalah sebagai berikut :

\section{H1 : Terdapat perbedaan secara signifikan terhadap tingkat pemahaman aktiva antara mahasiswa berasal dari SMK Jurusan Akuntansi, SMA Jurusan IPS dan Madrasah Aliyah Umum.}

Dari tabel diatas terlihat bahwa variabel aktiva secara statistik chi-square tabel sebesar 124,342 > chi-square hitung sebesar 2,077, sedangkan berdasarkan nilai probabilitas signifikansi sebesar 0,354 > 0,05 maka H1 ditolak. Hasil tersebut menunjukkan bahwa tidak terdapat perbedaan secara signifikan terhadap pemahaman tentang aktiva antara mahasiswa yang berasal dari SMK Jurusan Akuntansi, SMA Jurusan IPS, dan Madrasah Aliyah Umum. Pada variabel aktiva mean rank tertinggi dimiliki oleh mahasiswa yang berasal dari Madrasah Aliyah dengan angka 56,21, dengan demikian maka dapat disimpulkan bahwa mahasiswa yang berasal dari Madrasah Aliyah lebih memahami tentang aktiva dibandingkan mahasiswa yang berasal dari SMA pada peringkat kedua dengan angka 50,02 dan mahasiswa yang berasal dari SMK pada peringkat ketiga dengan angka 46,03.

Hasil ini mendukung penelitian terdahulu yang dilakukan Sar'i, Irsyadsyah, dan Djamil (2010) dan Novius (2010) yang menunjukkan bahwa pemahaman tentang aktiva antara mahasiswa Jurusan Akuntansi S1 UIN Suska Riau yang berasal dari SMK Jurusan Akuntansi, SMA Jurusan IPS, dan Madrasah Aliyah Umum tidaklah berbeda dan bisa dikatakan sama atau identik. 
H2 : Terdapat perbedaan secara signifikan terhadap tingkat pemahaman kewajiban antara mahasiswa berasal dari SMK Jurusan Akuntansi, SMA Jurusan IPS dan Madrasah Aliyah Umum.

Dari tabel diatas terlihat bahwa variabel Kewajiban secara statistik chisquare tabel sebesar 124,342 > chi-square hitung sebesar 1,653, sedangkan berdasarkan nilai probabilitas signifikansi sebesar 0,438>0,05 maka H1 ditolak. Hasil tersebut menunjukkan bahwa tidak terdapat perbedaan secara signifikan terhadap pemahaman tentang Kewajiban antara mahasiswa yang berasal dari SMK Jurusan Akuntansi, SMA Jurusan IPS, dan Madrasah Aliyah Umum. Pada variabel aktiva mean rank tertinggi dimiliki oleh mahasiswa yang berasal dari Madrasah Aliyah dengan angka 55,02, dengan demikian maka dapat disimpulkan bahwa mahasiswa yang berasal dari Madrasah Aliyah lebih memahami tentang aktiva dibandingkan mahasiswa yang berasal dari SMA pada peringkat kedua dengan angka 51,18 dan mahasiswa yang berasal dari SMK pada peringkat ketiga dengan angka 45,99.

Hasil ini mendukung penelitian terdahulu yang dilakukan Sar'i, Irsyadsyah, dan Djamil (2010) dan Novius (2010) yang menunjukkan bahwa pemahaman tentang kewajiban antara mahasiswa Jurusan Akuntansi S1 UIN Suska Riau yang berasal dari SMK Jurusan Akuntansi, SMA Jurusan IPS, dan Madrasah Aliyah Umum tidaklah berbeda dan bisa dikatakan sama atau identik.

H3: Terdapat perbedaan secara signifikan terhadap tingkat pemahaman modal antara mahasiswa berasal dari SMK Jurusan Akuntansi, SMA Jurusan IPS dan Madrasah Aliyah Umum.

Dari tabel diatas terlihat bahwa variabel modal secara statistik chi-square tabel sebesar 124,342 > chi-square hitung sebesar 1,850, sedangkan berdasarkan nilai probabilitas signifikansi sebesar 0,397 > 0,05 maka H1 ditolak. Hasil tersebut menunjukkan bahwa tidak terdapat perbedaan secara signifikan terhadap pemahaman tentang modal antara mahasiswa yang berasal dari SMK Jurusan Akuntansi, SMA Jurusan IPS, dan Madrasah Aliyah Umum. Pada variabel aktiva mean rank tertinggi dimiliki oleh mahasiswa yang berasal dari Madrasah Aliyah dengan angka 55,60, dengan demikian maka dapat disimpulkan bahwa mahasiswa 
yang berasal dari Madrasah Aliyah lebih memahami tentang aktiva dibandingkan mahasiswa yang berasal dari SMK pada peringkat kedua dengan angka 50,46 dan mahasiswa yang berasal dari SMK pada peringkat ketiga dengan angka 45,76.

Hasil ini tidak mendukung penelitian terdahulu yang dilakukan Sar'i, Irsyadsyah, dan Djamil (2010) yang menunjukkan bahwa pemahaman tentang modal antara mahasiswa Jurusan Akuntansi S1 UIN Suska Riau yang berasal dari SMK Jurusan Akuntansi, SMA Jurusan IPS, dan Madrasah Aliyah Umum berbeda dan bisa dikatakan tidak sama., dan mendukung penelitian yang dilakukan Novius (2010) yang menunjukkan bahwa pemahaman tentang modal antara mahasiswa Jurusan Akuntansi S1 UIN Suska Riau yang berasal dari SMK Jurusan Akuntansi, SMA Jurusan IPS, dan Madrasah Aliyah Umum tidaklah berbeda dan bisa dikatakan sama atau identik.

\section{KESIMPULAN DAN SARAN}

\section{Kesimpulan}

Dari ketiga variabel yang dijadikan pengukuran perbedaan tingkat pemahaman mahasiswa terhadap konsep dasar akuntansi yaitu aktiva, kewajiban, dan modal dinyatakan tidak terdapat pemahaman mahasiswa terhadap konsep dasar akuntansi. Dari nilai mean rank ketiga variabel maka terlihat bahwa mahasiswa yang berasal dari Madrasah Aliyah lebih memahami konsep dasar akuntansi dibandingkan mahasiswa yang berasal dari SMK dan SMA. Penelitian ini menunjukkan tidak ada sebuah jaminan yang menyatakan bahwa mahasiswa yang berasal dari SMK Jurusan Akuntansi yang telah mendapatkan pembelajaran tentang akuntansi lebih banyak di sekolah mampu memahami mata kuliah dasardasar akuntansi dengan baik dibandingkan dengan mahasiswa yang berasal dari Madrasah Aliyah yang mendapat pembelajaran tentang akuntansi paling sedikit di sekolah.

\section{Saran}

Untuk penelitian selanjutnya diharapkan tidak hanya perguruan tinggi negeri dikota malang tetapi diperluas dengan penelitian pada perguruan tinggi swasta. Dan diharapkan dapat menggunakan sampel serta jumlah kuisioner yang disebarkan lebih banyak. Mahasiswa akuntansi yang berasal dari SMK jurusan 
akuntansi, seharusnya lebih menonjolkan pemahaman dasar tentang akuntansi dibandingkan dengan mahasiswa yang berasal dari SMA dan madrasah aliyah yang memiliki pengetahuan tentang akuntansi yang lebih sedikit. Saran untuk penelitian selanjutnya adalah dengan mengembangkan atau mengganti variabel dengan mempertimbangkan beberapa variabel seperti pemahaman jurnal, pemahaman laporan keuangan, pemahaman buku besar, dan lain-lain.

\section{DAFTAR PUSTAKA}

Baridwan, Zaki.1992. Intermediate Accounting. Yogyakarta : BPFE

Budhiyanto, Suryanti J. Dan Nugroho, Ika P. 2004. "Pengaruh Kecerdasan Emosional terhadap Tingkat Pemahaman Akuntansi". Jurnal Ekonomi Bisnis, Vol. X, No.2, Hal.260-281.

Herry dan Hamin. 2005. Tingkat Kepemilikan Manajerial dan Nilai Perusahaan: Bukti Empiris pada Perusahaan Publik di Indonesia. Ikatan Sarjana Ekonomi Indonesia (ISEI) Cabang Surabaya. Simposium Riset Ekonomi II. Surabaya.

Indriantoro, Nur \& Bambang Supomo. 2002. Metode Penelitian Bisnis untuk Akuntansi dan Manajemen. Yogyakarta : BPFE.

Janes, Troy D. 2003. Accruals, Financial Distres, and Debt covenants. Dissertation at the university of Michigan Business School.

Kieso, Donald E., Jerry J. Weygandt, dan Terry D. Warfield. 2002. Akuntansi Intermediate. Jakarta : Penerbit Erlangga.

Mudyahardjo, Redja. 2008. Filsafat Ilmu Pendidikan. Bandung : PT. Remaja Rosdakarya, cetakan kedua.

Munawir, S. 2004. Analisa Laporan Keuangan. Yogyakarta: Penerbit Liberty.

Nana, Sudjana. 2005. Belajar Dasar-dasar Proses Mengajar. Bandung: Sinar Baru Algesindo.

Novius, Andri. 2010. Analisis Pemahaman Mahasiswa Akuntansi dalam Menghadapi Mata Kuliah Dasar-dasar Akuntansi. Skripsi, Tidak Dipublikasikan. Riau, Fakultas Ekonomi UIN Suska Riau.

Sanjaya, Wina. 2005. Pembelajaran dalam Implementasi Kurikulum Berbasis Kompetensi. Jakarta : Prenada Media.

Sar'i, Irsyadsyah,dan Jamil. 2010. Analisis Tingkat Pemahaman Mahasiswa Akuntansi Terhadap Konsep Dasar Akuntansi. Simposium Nasional Akuntansi XIII, Purwokerto. 
Suwardjono. 1999. Menanankan Akuntansi di Tingkat Pengantar. Jurnal Ekonomi dan Bisnis Indonesia, Vol. 14 No.1 Hal 71-87. 